\title{
The Role of English Language and Literature on the Cultivation of Students' Language Ability
}

\author{
Chen Shuang ${ }^{1, a}$ \\ ${ }^{1}$ College of Humanities and Law, Northeast Agricultural University \\ a13212812621@163.com
}

Keywords: English language and literature; Students; Language ability; Culture; Role; strategy

\begin{abstract}
Education of English language and literature plays an important role in promoting students' language ability. Here analyses the importance of cultivating students' language ability, put forward the components of students' language ability, analysis of the English language and literature for the specific role to improve students language skills, and explore in the English language and literature education, the strategies to improve students' language skills, to realize the development of students' language ability, enhance the teaching of English language and literature education has a positive role.
\end{abstract}

\section{The importance of cultivating students' language ability}

Language expression ability is a basic ability that talents must have in today's society. In the modern society, most of the communication between people depends on language. For the students, improve their ability of language expression is an important means to improve students ability to communicate, good language capacity are also students establish a good interpersonal relationship, the basis of better integration into society. At present, the social competition is fierce, and students must have strong language ability to handle various relationships effectively

Can develop effectively in the fierce competition of the society. But through the investigation, we found that the students' language ability is poor, now they are in the process of working with people, even it's hard to put the thought in my heart said successfully expressed in appropriate language. being

There are many reasons for this problem. Students' language ability is low and the modern students are only children, in the family environment, they lack the communication object, equal to its position in the family, now students are addicted to the online world, they are more in a state of solitude, lack of communication practice, it is the important reason affecting the development of the students' ability of communication. When such students go to society, it is difficult to integrate effectively into the society, not to talk about effective development. More importantly, in the modern society, a large number of need is a strong English language expression ability of talented person, even if not engaged in foreign trade industry, but the students in the life, in the work can be applied to the English, modern society to cultivate the students' English language competence is very important. And now the English language and literature education to cultivate the students' language ability, to cultivate the students' ability of English is a big role, English language and literature education can effectively provide students with knowledge of literature and language, can expand students' thinking space, enrich the students' field of vision, make students experience language practice, can effectively promote the students' language ability, therefore, in school education, the need to attach importance to English language and literature education, the need to pay attention to training students' language ability.

\section{The elements of language competence}

\section{Basic language knowledge}

Language knowledge is the foundation of language use, only to master the necessary basic knowledge of language, the students to be effective application language basic knowledge in language communication, the language ability of students to get training. If there is no basic 
knowledge of language,

Students are difficult to understand language specification, it is difficult to carry out language communication, both sides of communication can be difficult to achieve communication, language communication activities will be difficult to achieve, therefore, basic knowledge of language is the basic elements of language proficiency. Language knowledge includes two aspects of content, the first is the lexical knowledge, is the so-called lexical words used method, only to master the specific application of the new words, to appropriate use of vocabulary in language expression. The second is syntax, and syntax is the method of sentence construction, including the composition of simple sentences and the organization of complicated sentences. Only by mastering the syntax can students follow one

The language ability can be improved by the expression of the sentence

\section{Language communication skills in different contexts}

Mastered the basic language knowledge, language communication ability of students can get a preliminary development, but in the process of daily language communication, the students also need to be able to in the specific language environment, able to communicate properly applied language, can this kind of communication

Force is a deeper language communication ability, students have to possess the language ability, must be able to master the different context of language communication skills, therefore, the essence of language communication skills and language competence. The process of language communication is a complicated process. In the same sentence, different people say that there will be different meanings, and in different situations, the effect of their expression will be different. In different language environment, even if is to express the same meaning, different people the choice of expression way is different, the expression of a euphemism, have explicit expression, its expression content is the same, but the effect is also different. Therefore, the language expression must be able to combine with the specific context and express it according to the context, so that the speaker's ideology can be properly conveyed. This ability is a higher level of language ability. For students, it is necessary to master the language communication skills in different contexts. In the practice of language, it is necessary to constantly summarize the language skills to further improve their language ability.

\section{Rhetoric of language}

Both use Chinese for communication, and use English for communication, in the process of communication, as the language communication needs to be through the use of rhetoric to achieve a kind of communication, the effect of the peculiar in this way, can make the communication activities carry on effectively. To achieve this characteristic communication effect requires the use of the language rhetoric art, therefore, the language rhetoric art is also the element of language ability. In the process of language communication, the application of rhetoric can achieve the following three communicative effects, the accuracy of statement,

The intelligibility of language communication and the appeal of language communication. That is to say, the use of rhetoric is to make the language more accurate, can accurately reflect the speaker's ideology, and with the aid of rhetoric, the speaker can make the language more easily accepted by the hearer, the understanding, even with the aid of rhetoric can make speakers with emotions, in this way, can effectively achieve the purpose of language communication. Therefore, mastering the art of language and rhetoric is also very important for improving the language ability.

\section{Taboos and expressions of life in different cultural backgrounds}

Language is an important tool for emotional expression. Language is not only affected by the context, but also influenced by different cultural background. Any form of language carries specific cultural information, and different languages have roots

According to different cultural background, the best communication effect can be achieved. Therefore, it is an important component of language ability to master the taboos and expressions of life in different cultural backgrounds. If the two sides of a different cultural background don't know each other

Cultural background differences, without understanding the different cultural life taboos of each 
other, it is difficult to really achieve effective communication, even a lot of misunderstanding, which affects the effect of communication. Therefore, when training students' language ability, need to be able to make the students master life taboo under different cultural background, so that the students can master the methods of language according to different cultures.

\section{The role of English language literature in cultivating students' language ability}

Literary language is the highest level of language application. In English language and literature, many works are the blueprint of students' learning of English language, and are also important for students to improve their language ability. In English language and literature, it can provide students with multiple levels.

The basic knowledge of language can demonstrate the skills of communication in English, while displaying the differences between western culture and Oriental weihua and promoting the taboos of various language cultures. Therefore, English language and literature can improve students' English language expression and application ability in all aspects, and have a profound influence on the development of students' language ability. Specifically, we can analyze the impact from the following aspects:

\section{Provides examples of language usage}

Learning English language and literature, students can see many kinds of language communication as an example, in this instance, students can imitate for language expression, to improve the language ability of students has an important role in promoting. English language and literature can provide students with examples of the basic knowledge of language in dalian, providing a large number of word usage methods and sentence usage methods, In the process of reading, it can be affected. In addition, in the English language literature shows a lot of language use skills, in different language environment, should be performed if the language expression, in a particular context, how to select the appropriate statement successfully express the speaker's meaning, in this example also has a lot of work. This is also a promotion for the development of students' language abilities. Not only that, but also provides the necessary in the English language and literature rhetoric skills, students by reading the specific process of communication, can use rhetoric skills to master some language, to improve the language ability of students has great influence. In the English language and literature, students can clearly feel the cultural differences between east and west, can be in the context of a, deeply appreciate differences between the language application, for the students, according to the specific cultural properly the cultivation of the ability of language expression is also a kind of promotion. Therefore, the English language and literature provides an example of language expression for students, which has great influence on students' language ability.

\section{Can expand the student's language knowledge}

In the English language and literature, in every work of spread to the students the basic knowledge of the English language application, disseminating the knowledge of grammar application, language using the skills knowledge, the application of language rhetoric knowledge, etc., while, in the daily teaching, in the grammar explanation, the teacher can also through some examples for the interpretation of the grammar, but these students grammar knowledge is really hard to digest, the student to the statements use rules can not accurately understand, because, this kind of explanation is separated from the specific context. In the works of English language and literature, there is such a context in which students learn the language knowledge in the context, and the understanding and understanding of the language knowledge will be more thorough. Therefore, learning to expand effectively, this has a positive effect on improving students' language application ability and enriching students' language application skills.

\section{Enrich the language of the students}

English language and literature can enrich students' language expression. Firstly, through the reading comprehension of English language and literature, students' vocabulary can be greatly enriched, and in the specific context, students can master the exact expressions of these words . In addition, different schools of writers has different writing style, they have different language 
expression, reading these works, to enable students to master the diversity and richness of language expression, can improve students ability of language expression. Besides, in the English language and literature, students learn about the story of a lot of content, understand a lot of different character allusions, to understand a lot of literature knowledge, understand a lot of new ideas, new things. In the process of students' language communication, they will be influenced by these content, which will have an important influence on the language expression of students.

\section{English language and literature education improves students' language ability strategies}

In English language and literature education, to improve students' language ability, first of all, students should be guided to read and practice activities to improve their sense of language. In the teaching process of English language and literature, every teacher emphasizes the importance of language sense, but the sense of language training needs to be accomplished by a great deal of reading practice, which requires the accumulation of reading by students. Therefore, to cultivate students' good language ability, they need to be able to guide students to read extensively, from quantitative to qualitative change, thus improving students' language ability. Secondly, it is important to clarify the learning objectives of English literature so as to guide students' self-conscious learning and improve their language ability. In the teaching of English language and literature, some students only pay attention to the knowledge of language and literature, and pay no attention to the improvement of their own language ability. Thus, it is difficult for students to achieve the purpose of English language and literature study. Therefore, the goal of English language and literature learning is clearly defined, and the purpose of learning is clear, so that students can express their training consciously, so that they can effectively improve their language ability. In the teaching, teachers can set some topics for the students, let students discuss and analyze the subject, guide students to use their knowledge of the expression meaning expressed themselves in class. If a student answer the topic content is not comprehensive, can let the other students, in this way, can promote the expression of students enthusiasm, for promoting a positive role in promoting language proficiency.

\section{References}

[1] Study on the role of English language and literature in improving students' language application ability [J]. English square 2016(3).

[2] longling yun. Discussion on teaching methods of English language and literature [J]. Campus English, 2014(35).214 